\title{
Anaerobic digestion of banana winery effluent for biogas production
}

\author{
Sophia Saidi Bakili ${ }^{1{ }^{* *}}$, Amare Gessesse ${ }^{2}$, Kelvin Mtei $^{1}$, Karoli Nicholus Njau ${ }^{1}$ \\ ${ }^{1}$ Dept. of Water, Environmental Sciences and Engineering (WESE), Nelson Mandela-African Institution of Science and Technology, \\ Arusha, Tanzania \\ ${ }^{2}$ School of Life Science and Bioengineering, Nelson Mandela-African Institution of Science and Technology, Arusha, Tanzania
}

\section{Email address:}

bakilis@nm-aist.ac.tz (S. S. Bakili), amare.gessesse@nm-aist.ac.tz (A. Gessesse), kelvin.mtei@nm-aist.ac.tz (K. Mtei), karoli.njau@nm-aist.ac.tz (K. N. Njau)

\section{To cite this article:}

Sophia Saidi Bakili , Amare Gessesse, Kelvin Mtei, Karoli Nicholus Njau. Anaerobic Digestion of Banana Winery Effluent for Biogas Production. International Journal of Environmental Protection and Policy. Vol. 2, No. 5, 2014, pp. 168-173.

doi: $10.11648 /$ j.ijepp.20140205.14

\begin{abstract}
The efficiency of banana winery effluent (BWE) in biogas production through improving fermentation process was investigated in this study. The study was conducted in a batch system under mesophilic temperature of $35^{\circ} \mathrm{C}$ achieved by using controlled thermostat waterbath. Two sets of experiments (labeled as experiment 1 and experiment 2) with five reactors each, were performed in the laboratory. For experiment 1, reactor A was treated as a control with no addition of urea while $1 \mathrm{~g}, 2 \mathrm{~g}, 3 \mathrm{~g}$ and $4 \mathrm{~g}$ of urea were added in reactors B,C,D and $\mathrm{E}$ respectively. For experiment 2, different amount of sucrose, that is $0.18 \mathrm{~g}, 0.27 \mathrm{~g}, 0.36 \mathrm{~g}$ and $0.44 \mathrm{~g}$ were added in the reactors B, C, D and E correspondingly, and reactor A without sucrose addition was used as the control .Results for experiment 1 revealed that reactor A produced largest volume of biogas (1.93L) followed by reactor B with least amount of urea where $1.37 \mathrm{~L}$ of biogas was generated. Other reactors produced smaller volume of biogas during the study period. For experiment 2 results indicated large volume of biogas (2.72L) was produced in reactor $\mathrm{C}$ with $0.27 \mathrm{~g}$ of sucrose followed by reactor $\mathrm{D}(2.71 \mathrm{~L})$ with $0.36 \mathrm{~g}$ sucrose. The biogas produced contained $68.9 \%-$ $74.6 \%$ methane $\left(\mathrm{CH}_{4}\right)$. This study concluded that addition of nitrogen source does not increase biogas production from Banana winery effluent while addition of carbon source is important as a source of energy for enhancing $\mathrm{C}$ : $\mathrm{N}$ ratio for process stability and biogas production.
\end{abstract}

Keywords: Anaerobic Digestion, Banana Winery Effluent, Biogas, C: N Ratio

\section{Introduction}

In recent years, there is tremendous growth of agroprocessing industries in Tanzania. These industries produce enormous volumes of high strength organic effluents which if treated properly can serve as a source of energy [1]. The presence of biodegradable components in the effluents together with the advantages of anaerobic process over other treatment methods makes the anaerobic digestion process a remarkable option [2]. Banana Investment Limited (BIL) in Arusha, Tanzania produces wine and alcoholic beverages from ripe banana. In the process approximately $400 \mathrm{~m}^{3}$ of high strength organic wastewater are released daily [3].

These winery effluents are highly polluted and can produce severe negative effects to the environment if they are discharged without sufficient treatment [4]. However these wastes are good sources of biogas due to presence of highly degradable organic matter [2] .Biogas is a methane rich fuel gas produced by anaerobic breakdown or digestion with the help of methanogenic bacteria under oxygen free environment [5].Anaerobic digestion technology of biogas production has been widely used in the treatment of wastewater from winery industries [6] and can be used as depollution tool as well as for energy recovery.

Although anaerobic treatment of winery wastewater produced from grape-wine has been widely documented [7], the banana winery effluent (BWE) produced from ripe banana as one of the potential bioprocess problem but a good source of biogas is underexploited and so far there is no academic literature available presenting the efficiency of BWE in biogas production. The present study aimed at 
exploring the efficiency of BWE in biogas production through enhancing its fermentation process.

\section{Materials and Methods}

This study was conducted at Nelson Mandela African Institution of Science and Technology (NM-AIST) and Banana Investment Limited (BIL) laboratories. Experimental setup and biogas analysis was done at NM-AIST laboratory whereas influent and effluent analyses were carried out at BIL laboratory (Table 2 and 3). The composition of raw BWE was characterized at Ngurdoto Defluoridation center (Table 1).

\subsection{Sample Collection and Treatment}

The substrate used for this research was banana winery effluent (BWE) collected from Banana Investment Limited (BIL) in Arusha, Tanzania. The inoculum (cow slurry) was obtained from existing domestic bio-digesters around the NM-AIST. Tree debris, grasses and other large particles were removed from the slurry by hand picking technique prior to the reactor feeding. Thirteen litres (13L) of BWE and five litres $(5 \mathrm{~L})$ of cow slurry were used for each experiment. Fresh samples of BWE and cow slurry were collected when required.

\subsection{Experimental Procedures and Reactor Set Up}

The side-arm conical flask (Pyrex) of 1L capacity was used as a reactor. One Litre (1L) of the slurry was prepared for each reactor. The working volume for every reactor of each experiment was made to $850 \mathrm{~mL}$. About $150 \mathrm{~mL}$ of reactor content was kept in $4^{0} \mathrm{C}$ refrigerator for volatile solid (VS), Chemical oxygen demand (COD), total solids (TS) and Volatile fatty acid (VFA) analysis.

\subsubsection{Experiment 1: The Nitrogen Source Supplementation}

In this experiment urea was used as nitrogen source. There were five reactors labeled as A, B, C, D and E prepared in triplicate. Reactor A was used as the control. The slurry in reactor A was prepared by mixing $800 \mathrm{~mL}$ of BWE and $200 \mathrm{~mL}$ of inoculum in the ratio of $4: 1$ respectively. The $\mathrm{pH}$ of the slurry was measured using the $\mathrm{pH}$ meter. The slurries for reactor $\mathrm{B}, \mathrm{C}, \mathrm{D}$, and $\mathrm{E}$ was prepared by mixing $800 \mathrm{~mL} B W E$ and $200 \mathrm{~mL}$ of inoculum in $4: 1$ ratio followed by addition of $1 \mathrm{~g}, 2 \mathrm{~g}, 3 \mathrm{~g}$, and $4 \mathrm{~g}$ of urea respectively, in order to investigate the effect of urea on the quantity of biogas produced. Each reactor was connected to 1Litre inverted measuring cylinder (used as biogas collecting apparatus ) filled with brine solution by means of rubber tube $(50 \mathrm{~cm}$ long and $10 \mathrm{~mm}$ diameter) positioned upright in the measuring cylinder. The acidified brine solution was prepared following the method adopted by [8]. All reactors were fitted with air-tight rubber stopper. Reactors were immersed about one-third in the controlled thermostat waterbath operated at $35^{\circ} \mathrm{C}$ and digestion process was allowed to proceed for 13 days, according to degradation method adapted from [9] with few modification. Biogas was collected from each digester and measured by water displacement method as described by [5]. Shaking was done twice a day at 9:00 AM and 9:00PM. Biogas produced from each reactor was recorded for 13days consecutively at 9:00PM.

\subsubsection{Experiment 2: The Carbon Source Supplementation}

In this experiment sucrose was used as carbon source. There were five reactors labeled as A, B, C, D and E prepared in triplicate. Reactor A was used as the control. The slurry in reactor A was prepared by mixing $800 \mathrm{~mL}$ of BWE and $200 \mathrm{~mL}$ of inoculum in the ratio of $4: 1$ respectively. The $\mathrm{pH}$ of the slurry was measured using the $\mathrm{pH}$ meter. The slurries for reactor $\mathrm{B}, \mathrm{C}, \mathrm{D}$, and $\mathrm{E}$ was prepared by mixing $800 \mathrm{~mL} \mathrm{BWE}$ and $200 \mathrm{~mL}$ of inoculum in $4: 1$ ratio followed by addition of $0.18 \mathrm{~g}, 0.27 \mathrm{~g}, 0.36 \mathrm{~g}$, and $0.44 \mathrm{~g}$ of sucrose respectively, in order to investigate the effect of sucrose on the amount of biogas produced. Each reactor was connected to 1Litre inverted measuring cylinder (used as biogas collecting apparatus ) filled with acidified brine solution by means of rubber tube $(50 \mathrm{~cm}$ long and $10 \mathrm{~mm}$ diameter) positioned upright in the measuring cylinder. The acidified brine solution was prepared following the method adopted by [8]. All reactors were fitted with air-tight rubber stopper. Reactors were immersed about one-third in the controlled thermostat waterbath operated at $35^{\circ} \mathrm{C}$ and digestion process was allowed to proceed for 15days, according to degradation method adapted from [9] with slight modifications. Biogas was collected from each digester and measured by water displacement method as described by [5]. Shaking was done twice a day at 9:00 AM and 9:00PM. Biogas produced from each reactor was recorded for 15 days consecutively at 9:00PM.

\subsection{Analytical Methods}

The influent and effluent samples from biogas plant were collected and analyzed for physicochemical parameters: total solids (TS), volatile solids (VS), total suspended solids (TSS) and chemical oxygen demand (COD). The pH was determined by portable $\mathrm{pH}$ meter (HANNA model).In addition to the above mentioned parameters BWE was also characterized for the reactive phosphate $\left(\mathrm{PO}_{4}{ }^{3-}\right)$, Total Organic Carbon (TOC) and Kjeldahl Nitrogen (TKN). Biogas composition was analyzed by using BIOGAS 5000 gas analyzer.

\subsubsection{Total Organic Carbon (TOC)}

Total organic carbon (TOC) was determined with a TOC analyzer (Sievers 900 Portable). The sample was processed by taking $5 \mathrm{~mL}$ of the sample and diluted to $20 \mathrm{~mL}$ distilled water. Then, the diluted sample was introduced in the machine in which it took the required quantity of the sample for analysis. The TOC analyzer is auto reagents featured and therefore derives and applies the optimum oxidizers and flowrate for the measurement of a given sample. In this 
equipment the sample was first acidified by phosphoric acid and then the organic matter of the sample was oxidized by persulphate to $\mathrm{CO}_{2}$. The TOC of the sample was automatically measured by the membrane-conductivity detection system used in the analyzer [10].

\subsubsection{Kjeldahl Nitrogen (TKN)}

The TKN of banana winery effluent (BWE) was measured by semi-micro-kjeldahl method described in [11]. About $50 \mathrm{~mL}$ of sample was measured quantitatively and transferred into a distillation flask. About $5 \mathrm{ml}$ of borax reagent was added to the sample after the assembly of a distillation unit. $10 \mathrm{ml}$ of Boric acid (4\%) was filled in collection distillate flask. About $40 \mathrm{~mL}$ of distillate was collected and treated with standard $\mathrm{HCl}$ solution of about $0.1 \mathrm{M}$.

\subsubsection{Phosphate $\left(\mathrm{PO}_{4}{ }^{3-}\right)$}

The reactive phosphate of BWE was measured following procedures described in [12]. The spectrophotometric method Hach DR/2000 was used. The sample was processed by diluting $10 \mathrm{~mL}$ sample to $50 \mathrm{~mL}$ distilled water. Then, $25 \mathrm{~mL}$ of the diluted solution was placed in the cuvette and phosVer 3 phosphate powder pillow was added. The phosphate was detected at wavelength of $890 \mathrm{~nm}$.

\subsubsection{Total Solids (TS), Total Suspended Solids (TSS) and Volatile Solids (VS)}

The samples were subjected to dry-air oven at $105^{\circ} \mathrm{C}$ for one hour for TS and TSS determination. For VS analysis, the loss on ignition method was used whereby samples were subjected to muffle furnace at $550^{\circ} \mathrm{C}$ for 3 hours. The TS, VS and TSS were analyzed according to procedures described in [11].

\subsubsection{Chemical Oxygen Demand (COD)}

The closed reflux, titrimetric method was used for COD determination. The sample $(5 \mathrm{ml})$ was diluted to with distilled water in $100 \mathrm{~mL}$ volumetric flask. Then, $2.5 \mathrm{ml}$ of the diluted sample was treated with $1.5 \mathrm{~mL}$ digestion solution followed by $3.5 \mathrm{~mL}$ sulfuric acid reagent. The ampules were tightly sealed and placed in the oven at $150^{\circ} \mathrm{C}$ for two hours as described in [11].

\section{Results and Discussion}

The efficiency of BWE to produce biogas was investigated based on the volume of biogas produced, total solids (TS) and (volatile solids) VS reduction as well as COD removal of each experimental digester.

\subsection{Effluent Characterization}

Table 1 shows the composition of raw banana winery effluent (BWE). It was observed that the $\mathrm{pH}$ of BWE was nearly neutral and therefore required no adjustment. According to literature, at the $\mathrm{pH}$ range of 6.5 to 8.2 methanogens become very active [13]. The values for chemical oxygen demand and total suspended solid indicate that the BWE might be a good substrate for biogas production provided that the conditions in the digester are satisfactory to favor the growth of anaerobic bacteria. The $\mathrm{C} / \mathrm{N}$ ratio of the $\mathrm{BWE}$ is lower and there is a need of adjusting it to the required range of 20-30:1 for optimal digester performance [14].

Table 1. Composition of Raw BWE collected from Banana investment Limited (BIL)

\begin{tabular}{ll}
\hline Parameter & Concentration* \\
\hline $\mathrm{pH}$ & 6.9 \\
chemical oxygen demand $(\mathrm{g} / \mathrm{L})$ & 5.3 \\
Total organic carbon $(\mathrm{g} / \mathrm{L})$ & $3.5 \times 10^{-2}$ \\
Total Kjeldahl Nitrogen $(\mathrm{g} / \mathrm{L})$ & $7.7 \times 10^{-3}$ \\
Total suspended solids $(\mathrm{g} / \mathrm{L})$ & 2.2 \\
$\mathrm{PO}_{4}{ }^{3-}(\mathrm{g} / \mathrm{L})$ & $7.3 \times 10^{-3}$ \\
$\mathrm{C} / \mathrm{N}$ ratio & $5: 1$ \\
\hline
\end{tabular}

* Mean of triplicate determination

\subsection{Experiment 1: Nitrogen Source Supplementation}

Results of the analysis of influent and effluent samples for the reactor A, B, C, D and E are shown in Table 2. It can be seen that the initial $\mathrm{pH}$ is within the range of highly microbial activity. The total solids (TS) and volatile solids (VS) following the amount of urea added to each reactor as shown in the Table 2, are in the appreciable amount and thus they might be good candidates in biogas production process as pointed out by [15] if the reactor condition is stable. However, the COD in reactor $\mathrm{E}$ was lower than expected taking into consideration the amount of urea added and also the amount of BWE and inoculum were in the same ratio ( $4: 1$ respectively) in all digesters. This might be attributed to insufficient mixing in the time of sampling. This experiment aimed at investigating the effect of different urea concentration added (Table 2) on the biogas production.

At the beginning of the digestion process, the $\mathrm{pH}$ of the mixtures in all reactors was in the range of 7.4-7.7 (Table 2). This range is within that of optimal methanogens activity of 6.5-8.2 as reported in literatures [16]. Figure 1 shows the cumulative biogas production following urea addition, for 13 days experimental period. Biogas production was low during initial stages and then increased gradually throughout the study period in all digesters. This might be due to lag phase of microbial growth whereby anaerobic bacteria acclimatize to the new environment. The similar trend was observed by [17]. The highest volume of biogas (1.93L) was measured in reactor $\mathrm{A}$ with no urea addition followed by reactor $\mathrm{B}, \mathrm{C}, \mathrm{D}$ and $\mathrm{E}$ which had $1.37 \mathrm{~L}, 0.22 \mathrm{~L}$, and $0.12 \mathrm{~L}$ and $0.08 \mathrm{~L}$ respectively. This shows that biogas yield decreased as urea concentration increased (Figure 1). This trend was probably contributed to the increase in biodigester effluent $\mathrm{pH}$ (as shown in Table 2) which suggests the increase in ammonia concentration that inhibits microbial activities. Reference [18, 19] reported that the increase in $\mathrm{pH}$ is due to accumulation of 
free ammonia which has inhibitory effects to methanogens. High concentration of ammonia nitrogen is toxic to anaerobes thus decrease the efficiency of the digestion and upset the process. Urea metabolism results in the formation of ammonia due to nitrogen consumption by anaerobic bacteria. As urea concentration increases, resulted in the elevated nitrogen levels (as undissociated ammonia) in the digester which is toxic to methanogens and hence digestion process was impaired. At high nitrogen levels the $\mathrm{C}$ : $\mathrm{N}$ ratio is lowered and resulting to ammonia toxicity [20]. These results deviate slightly from the findings of [9] who reported on the decrease of biogas yield with addition of more than $0.2 \mathrm{~g} / 125 \mathrm{ml}$ urea concentration to banana leaves for biogas production process. Results suggest for the suitability of BWE in biogas production without addition of urea. It is worthwhile to note that the optimal range of quantity of urea to be added in the reactor as nitrogen supplement have not yet established. This study found that the urea concentration exceeding $1 \mathrm{~g} / \mathrm{L}$ will negatively affect biogas production and hence low biogas yield will be achieved as shown in Figure 1.

Table 2. Properties of biodigester content for different amount of urea added in each digester before and after digestion

\begin{tabular}{|c|c|c|c|c|c|c|c|c|c|}
\hline Reactor & $\begin{array}{l}\text { Urea } \\
\text { concentration } \\
(\mathrm{g} / \mathrm{L}) \\
\end{array}$ & $\begin{array}{l}\text { Initial } \\
\text { pH* }\end{array}$ & Final pH* & $\begin{array}{l}\text { Influent } \\
\text { TS (g/L)* }\end{array}$ & $\begin{array}{l}\% \mathrm{TS} \\
\text { removal* }\end{array}$ & $\begin{array}{l}\text { Influent } \\
\text { VS (g/L)* }\end{array}$ & $\begin{array}{l}\text { \%VS } \\
\text { removal* }\end{array}$ & $\begin{array}{l}\text { Influent } \\
\operatorname{COD}(\mathrm{g} / \mathrm{L}) \\
\text { * }\end{array}$ & $\begin{array}{l}\% \text { COD } \\
\text { removal* }\end{array}$ \\
\hline A & 0 & 7.4 & 7.6 & 13.7 & 77.7 & 5.2 & 46.2 & 8 & 88.9 \\
\hline B & 1 & 7.7 & 7.9 & 13.2 & 61.7 & 5.8 & 40.6 & 11.6 & 73.1 \\
\hline $\mathrm{C}$ & 2 & 7.7 & 8.3 & 13.4 & 43.1 & 4.9 & 16.4 & 10.2 & 21.7 \\
\hline $\mathrm{D}$ & 3 & 7.7 & 8.6 & 13.6 & 44.6 & 4.6 & 18.3 & 10.7 & 25 \\
\hline E & 4 & 7.6 & 8.8 & 13.9 & 46.6 & 5.2 & 44.9 & 7.6 & 5.9 \\
\hline
\end{tabular}

* Mean of triplicate determination, $\mathrm{COD}=$ Chemical Oxygen demand, $\mathrm{TS}=$ Total solids, $\mathrm{VS}=$ Volatile solids

The COD removal efficiency of the reactors was in the order of $\mathrm{A}>\mathrm{B}>\mathrm{D}>\mathrm{C}>\mathrm{E}$. Reactor A with BWE only had $88.9 \%$ COD removal efficiency (Table 2). This suggests that the operating conditions were favorable to both acidogenic and methanogenic bacteria. This result is comparable to values obtained by [16] that did research on anaerobic treatment of winery wastewater using laboratory-scale multi-and single-fed filters at ambient temperatures, and obtain of $85 \%$ COD removal. Reactor $\mathrm{E}$ with $4 \mathrm{~g}$ Urea achieved $5.9 \%$ COD removal which is low compared to other reactors (Table 2).

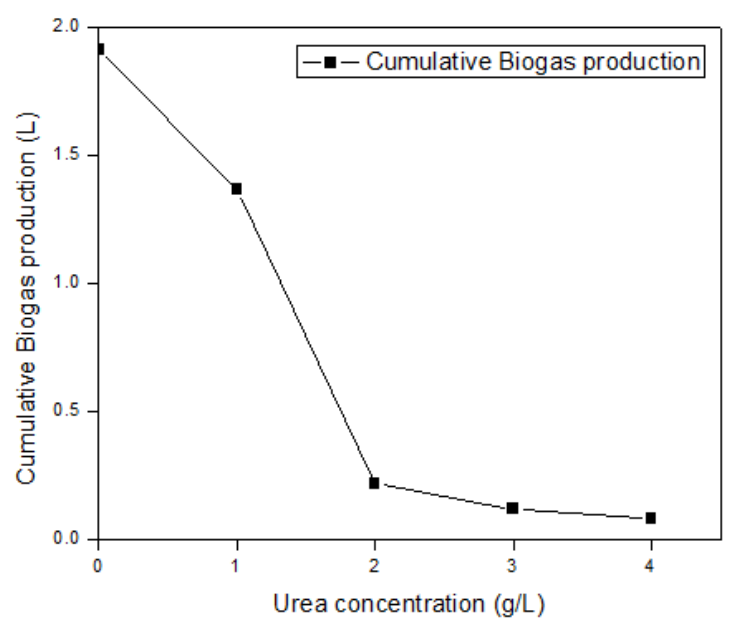

Figure 1. Cumulative biogas production as a function of urea added in each reactor

This was probably due insufficient methanogen population to act upon the given organic matter as a result of ammonia accumulation which was thought to kill methanogens and reduce its population. Initially, TS and VS amount were high as shown in table 2. However at the end of the experiment (13 days) there was substantial reduction in TS and VS (Table 2) which resulted from being consumed by acidogenic and methanogenic bacteria to produce methane. Reference [21] also reported the similar trend. Furthermore, VS/TS ratio in all digesters was approximately 0.3 with little variation indicated that there was adequate mixing of the biodigester content thus preventing the accumulation of grit [17]. Sufficient mixing of the digester content provides an intimate contact between microorganisms and substrate for enhancing the bio methanation process and therefore successfully accomplishes the anaerobic treatment of organic rich wastewater $[17,20]$. The Volatile fatty acids (VFA) to Alkalinity (ALK) ratio was below 0.1 for reactor A and B which indicate that digester were operated under stable conditions. However there was slightly instability condition in digester $\mathrm{C}, \mathrm{D}$ and $\mathrm{E}$ (VFA/ALK were above 0.4 ) probably due to low alkalinity and elevated $\mathrm{pH}$ which affects methanogen activities. The VFA/ALK below 0.4 is crucial for stability of biodigester [22].

\subsection{Experiment 2: Carbon Source Supplementation}

Table 3 show results of the biodigester influent and effluent following different amount of sucrose added in each reactor. The initial $\mathrm{pH}$ of slurries of each reactor in this experiment was within the range of $6.5-8.2$ of highly methanogenic activities [16]. The amount of TS, VS and COD suggest that the slurries prepared might be good source of biogas production. However, there is fluctuation in COD trend as sucrose concentration increased from $0.27 \mathrm{~g} / \mathrm{L}$ to $0.44 \mathrm{~g} / \mathrm{L}$ as shown in Table 3 . It was expected that COD will increase following increased sucrose concentration. This might result from insufficient mixing during sampling and treatment prior to titration or during titration. But this fluctuation does not interfere with biogas yield obtained. The aim of this experiment was to examine the impact of different sucrose concentration added in reactors (Table 3) on the biogas yield by enhancing the $\mathrm{C} / \mathrm{N}$ ratio to the acceptable range of 20-30:1 described in literatures [23]. 
These sucrose concentrations were chosen with respect to $\mathrm{C} / \mathrm{N}$ ratio of raw $\mathrm{BWE}$ (Table 1) which suggest that $\mathrm{BWE}$ has high nitrogen concentration than carbon and thus carbon supplementation is necessary.

There was substantial biogas production in all reactors, although reactor $\mathrm{C}$ with sucrose concentration of $0.27 \mathrm{~g} / \mathrm{L}$ was the best $(2.72 \mathrm{~L})$ as shown in Figure 2. This indicates that the $\mathrm{C}: \mathrm{N}$ ratio in the range of 20-30:1 is necessary for enhancing fermentation process in biogas production as reported by [14]. Additionally, C: $\mathrm{N}$ ratio of 20:1 which correspond to $0.27 \mathrm{~g} / \mathrm{L}$ sucrose concentration was optimal in improving fermentation process and hence maximum biogas production when using BWE as a substrate.

Table 3. properties of biodigester content for different amount of sucrose added in each reactor before and after digestion process

\begin{tabular}{|c|c|c|c|c|c|c|c|c|c|}
\hline Reactor & $\begin{array}{l}\text { Amount of } \\
\text { Sucrose (g/L) }\end{array}$ & Initial pH* & Final pH* & $\begin{array}{l}\text { Influent } \\
\text { TS (g/L)* }\end{array}$ & $\begin{array}{l}\text { \%TS } \\
\text { removal* }\end{array}$ & $\begin{array}{l}\text { Influent } \\
\text { VS (g/L)* }\end{array}$ & $\begin{array}{l}\text { \%VS } \\
\text { removal* }\end{array}$ & $\begin{array}{l}\text { Influent } \\
\text { COD (g/L)* }\end{array}$ & $\begin{array}{l}\% \text { COD } \\
\text { removal* }\end{array}$ \\
\hline A & 0 & 6.7 & 7.5 & 14.4 & 59.2 & 5.1 & 59.5 & 19.6 & 86.4 \\
\hline B & 0.18 & 6.7 & 7.4 & 12.5 & 62.4 & 3.9 & 48.3 & 20.4 & 87 \\
\hline $\mathrm{C}$ & 0.27 & 6.6 & 7.4 & 16.2 & 75.1 & 6.1 & 65.6 & 15.1 & 70.6 \\
\hline $\mathrm{D}$ & 0.36 & 6.6 & 7.4 & 10.6 & 68.9 & 5.7 & 57 & 17.8 & 70 \\
\hline $\mathrm{E}$ & 0.44 & 6.6 & 7.3 & 12.9 & 53.7 & 5 & 51 & 16 & 33.3 \\
\hline
\end{tabular}

* Mean of triplicate determination, $\mathrm{COD}=$ Chemical Oxygen demand, $\mathrm{TS}=$ Total solids, $\mathrm{VS}=$ Volatile solids

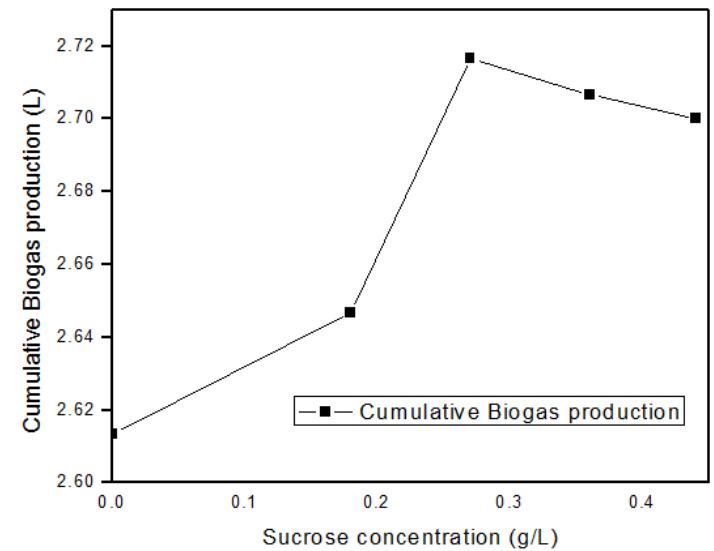

Figure 2. Cumulative biogas production as a function of sucrose added in each reactor

From Figure 2 it can be realized that biogas production increased with the increase in sucrose concentration but there was a limit of which further increase in sucrose concentration resulted in decreased biogas yield. There was increase in biogas production from reactor $\mathrm{A}$ (no sucrose added) to reactor $\mathrm{C}$ with $0.27 \mathrm{~g} / \mathrm{L}$ of sucrose which produced the highest amount of biogas. This was contributed to nutrient balance obtained with the addition of $0.27 \mathrm{~g}$ of sucrose which adjusted the carbon to nitrogen ratio to approximately $20: 1$ which is optimal $\mathrm{C}$ : $\mathrm{N}$ ratio when using BWE as a substrate in biogas production process. Also the increased biogas production might be attributed to stable conditions especially $\mathrm{pH}$ (Table 3), since anaerobic microbes require a neutral to slightly alkaline environment for proper growth and metabolic activities. This was also reported by [9]. However, further increase in sucrose concentration to $0.36 \mathrm{~g}$ and $0.44 \mathrm{~g}$ of sucrose the biogas yield decreased. This phenomenon was perhaps due to low nitrogen levels resulting to high carbon to nitrogen ratio and hence inhibited the rate of digestion. To balance nutrition the $\mathrm{C}: \mathrm{N}$ ratio must range from 20 to $30: 1$ [24].

Before digestion, the initial $\mathrm{pH}$ in all reactors were in the range of 6.6 to 6.7 as shown in Table 3, which was within the acceptable range for growth of anaerobic bacteria.
Furthermore at the end of experiment the final $\mathrm{pH}$ was found to be in the range of 7.3-7.5 (Table 3) which suggests that there was stable conditions in all reactors throughout the study period and thus VFA produced by acidogens were metabolized to methane by methanogenic bacteria. The VFA/Alkalinity ratio of the effluent was below 0.4 . This indicates that stable conditions were achieved in all reactors. Reference [22] reported that VFA/Alkalinity ratio above 0.4 will cause reactor instability.

From Table 3, it can be observed that the COD removal efficiency were $86.4 \%, 87 \%, 70.6 \%, 70 \%$ and $33.3 \%$ for reactor $\mathrm{A}, \mathrm{B}, \mathrm{C}, \mathrm{D}$ and $\mathrm{E}$ respectively, by which digester $\mathrm{B}$ was the best and $\mathrm{E}$ achieved low COD removal efficiency. Moreover, digester $\mathrm{C}$ attained the highest TS reduction of $75.10 \%$ and VS reduction of $65.57 \%$ compared to other reactors as shown in Table 3 and consequently contributed to the highest biogas and methane production as shown in Figure 2 .

\section{Conclusion}

Banana winery effluent does not necessarily need addition of nitrogen-rich substances to improve biogas production process. However, banana winery effluent requires some amount of carbohydrate to improve the anaerobic digestion process. Based on the findings of this study it can be concluded that banana winery effluent should be supplemented with carbon- rich nutrients for instance molasses (byproduct from sugar making process) to improve its $\mathrm{C}$ : $\mathrm{N}$ ratio and thus increase biogas production efficiency.

\section{Acknowledgment}

The authors would like to acknowledge the Nelson Mandela African Institute of Science and technology and COSTECH for financing this study. Also they are grateful to BIOINNOVATE project, Banana Investment Limited (BIL) managements, the working team at BIL laboratory and $\mathrm{Mr}$ Paranju from Kikwe village for their support. 


\section{References}

[1] K. Rajeshwari, M. Balakrishnan, A. Kansal, K. Lata, and V. Kishore, "State-of-the-art of anaerobic digestion technology for industrial wastewater treatment," Renewable and Sustainable Energy Reviews, vol. 4, pp. 135-156, 2000.

[2] M. M. Saleh and U. F. Mahmood, "Anaerobic digestion technology for industrial wastewater treatment," in Proceedings of the Eighth International Water Technology Conference, IWTC, Alexandria, Egypt, 2004, pp. 26-28.

[3] K. Njau, J. Kyambadde, M. Dawit, and N. Hermogene, "Integrated process for sustainable agro-process waste treatment and climate change mitigation in Eastern Africa," 2011 .

[4] F. Molina, G. Ruiz-Filippi, C. Garcıa, E. Roca, and J. Lema, "Winery effluent treatment at an anaerobic hybrid USBF pilot plant under normal and abnormal operation," Water Science \& Technology, vol. 56, pp. 25-31, 2007.

[5] S. Dhadse, N. Kankal, and B. Kumari, "study of diverse methanogenic and non-methanogenic bacteria used for the enhancement of biogas production," International Journal of Life Sciences Biotechnology and Pharma Research, vol. 1, pp. 176-191, 2012

[6] P. Vadlani and K. Ramachandran, "Evaluation of UASB reactor performance during start-up operation using synthetic mixed-acid waste," Bioresource Technology, vol. 99, pp. 8231-8236, 2008.

[7] A. Vlyssides, E. Barampouti, and S. Mai, "Wastewater characteristics from Greek wineries and distilleries," Water Science \& Technology, vol. 51, pp. 53-60, 2005.

[8] E. T. Iyagba, I. A. Mangibo, and Y. S. Mohammad, "The study of cow dung as co-substrate with rice husk in biogas production," Scientific Research and Essays, vol. 4, pp. 861-866, 2009

[9] M. Ekwenchi, "Effects of Buffering and Urea on the Quantity and Quality of Biogas From Banana Leaves as Alternative Renewable Energy Resource," Journal of Energy Technologies and Policy, vol. 3, pp. 16-22, 2013.

[10] GE Water and Process Technologies, Sievers 900 Portable Total Organic Carbon, Analyzer, Operation and Maintenance Manual. USA,2009.

[11] APHA. (1998). Standard Methods for the Examination of Water and Wastewater, 18th Edition, American Public Health Association, Washington, DC.

[12] Hach. (1992).Water Analysis Handbook,2nd Ed, Loveland, Colorado, USA
[13] B. S. Zeb, Q. Mahmood, and A. Pervez, "Characteristics and Performance of Anaerobic Wastewater Treatment (A Review)," Journal of the Chemical Society of Pakistan, vol. 35, pp. 217-232, 2013.

[14] E. Uzodinma, A. Ofoefule, J. Eze, I. Mbaeyi \& N.Onwuka. Effect of some organic wastes on the biogas yield from carbonated soft drink sludge. Sci. Res. Essays. 3: 401-405, 2008 .

[15] K. Kangle, S. Kore, V. Kore, G. Kulkarni. "Recent trends in anaerobic codigestion: a review". Universal Journal of Environmental Research and Technology, 2:210-219,2012.

[16] H.-Q. Yu, Q.-B. Zhao, and Y. Tang, "Anaerobic treatment of winery wastewater using laboratory-scale multi-and single-fed filters at ambient temperatures," Process Biochemistry, vol. 41, pp. 2477-2481, 2006.

[17] B. Abubakar and N. Ismail, "Anaerobic digestion of cow dung for biogas production," ARPN Journal of Engineering and Applied Sciences, vol. 7, pp. 169-172, 2012.

[18] Y. Chen, J. J. Cheng, and K. S. Creamer, "Inhibition of anaerobic digestion process: a review," Bioresource Technology, vol. 99, pp. 4044-4064, 2008.

[19] C. E. Manyi-Loh, S. N. Mamphweli, E. L. Meyer, A. I. Okoh, G. Makaka, and M. Simon, "Microbial Anaerobic Digestion (Bio-Digesters) as an Approach to the Decontamination of Animal Wastes in Pollution Control and the Generation of Renewable Energy," International journal of environmental research and public health, vol. 10, pp. 4390-4417, 2013.

[20] M. Krishania, V.Kumar, V. K. Vijay, \& A . Malik, "Analysis of different techniques used for improvement of biomethanation process: A review". Fuel, 106, 1-9 ,2013

[21] T. Aragaw, M. Andargie \& A. Gessesse. "Co-digestion of cattle manure with organic kitchen waste to increase biogas production using rumen fluid as inoculums". Int J Phys Sci, 8, 443-450,2013.

[22] E. Behling, A. Diaz, G. Colina, M. Herrera, E. Gutierrez, E. Chacin, "Domestic wastewater treatment using a UASBreactor,"BioresourceTechnology,vol.61,pp.239-245,1 997.

[23] U. I. Uzowuru, N.-U. A. M. G. "Anaerobic co-digestion of fruit waste and abattoir effluent". Journal of Biological Sciences and Bioconservation Volume 3, March 2011.

[24] A. Saleh, E. Kamarudin, A. Yaacob, A. Yussof, and M. Abdullah, "Optimization of biomethane production by anaerobic digestion of palm oil mill effluent using response surface methodology," Asia - Pacific Journal of Chemical Engineering, vol. 7, pp. 353-360, 2012. 